anatomical basis of symptomatic hemidystonia. Brain 1985;108:463-83.

5 Cohen LG, Hallett M. Hand cramps: Clinical features and electromyoraphic patterns in a focal dystonia. Neurology 1988;38:1005-12.

6 Hughes M, McLellan DL. Increased co-activation of upper limb muscles in writer's cramp. $₹$ Neurol Neurosurg Psychiatry 1985;48:782-7.

7 Sheehy MD, Marsden CD. Writer's cramp, a focal dystonia Brain 1982:105:461-80.

8 Yanagisawa N, Goto A. Dystonia musculorum deformans. Analysis by electromyography. $\mathcal{F}$ Neurol $S c i$ 1971;13: 39-65.

9 Ghez C, Gordon S, Hening W. Trajectory control in dystonia. Adv Neurol 1988;50:141-55

10 Nakashima K, Rothwell JC, Day BL, Thompson PD, Shannon K, Marsden CD. Reciprocal inhibition between forearm muscles in patients with writer's cramp and other occupational cramps, symptomatic hemidystonia and hemiparesis due to stroke. Brain 1989;112: 681-97.

11 Rothwell JC, Day BL, Obeso JA, Berardelli A, Marsden $\mathrm{CD}$. Reciprocal inhibition between muscles of the hum

12 Panizza ME, Lelli $S$, Nilsson J, Hallett $M$. H-reflex recovery curve and reciprocal inhibition of H-reflex in different kinds of dystonia. Neurology 1990;40:824-48.

13 Van Der Kamp W, Berardelli A, Rothwell JC, Thompson PD, Day BL, Marsden CD. Rapid elbow movements in patients with torsion dystonia. F Neurol Neurosurg Psychiatry 1989;52:1043-9.

14 Sanes JN, Evarts EV. Psychomotor performance in Parkinson's disease. In: Delwaide PJ, Agnoli A, eds. Clinical Neurophysiology in Parkinsonism. BV North Holland: Elsevier 1985:117-32.

15 Hollerbach JM, Flash T. Dynamic interactions between limb segments during planar arm movements. Biol Cybern 1982;44:67-77.

16 Flash T, Hogan N. The coordination of arm movement: an experimentally confirmed mathematical model. an experimentally confirm

17 Georgopoulos AP. On reaching. Ann Rev Neurosci 1986; 9:147-70.

18 Woodworth RS. The accuracy of voluntary movement Physiological Monograph Suppl New York: Macmillan, 1899;13:1-114.

19 Flash $\mathrm{T}$, Inzelberg $\mathrm{R}$, Korczyn $\mathrm{AD}$. Kinematic properties of upper limb trajectories in Parkinson's disease. Exp Neurol 1992;118:215-26.
20 Viallet F, Trouche E, Beaubaton D, Legallet E. The role of visual reafferents during a pointing movement: comparative study between open-loop and closed-loop performances in monkeys before and after unilateral electrolytic lesion of substantia nigra. Exp Brain Res 1987;65:399-410.

21 Inzelberg $\mathrm{R}$, Kahana $\mathrm{E}$, Korczyn $\mathrm{AD}$. Clinical course of idiopathic torsion dystonia among Jews in Israel. $A d v$ Neurol 1988;50:93-100.

22 Korczyn AD. Genetics of idiopathic torsion dystonia in Ashkenazi Jews. In: Bonne-Tamir B, Adam A, eds. Genetic diversity among fews. Oxford: Oxford University Press, 1992:194-201

23 Winer. Statistical principles in experimental design. McGrawHill, 1971 .

24 Marsden CD. The mysterious motor function of the basa ganglia: the Robert Wartenberg lecture. Neurology 1982; 32:514-39.

25 Thompson PD, Berardelli A, Rothwell JC, Day BL, Dick IPR, Benecke $R$, Marsden $C D$. The coexistence of bradykinesia and chorea in Huntington's disease and its implications for theories of basal ganglia control of movement. Brain 1988;111:223-44.

$26 \mathrm{McCloseky}$ DL. Corollary discharge: motor commands and perception. In: Brooks VB, ed. Handbook of physiol and perception. In: Brooks $\mathrm{VB}$, ed. Handbook of physiolBethesda: American Physiological Association, 1981. Bethesda:

27 Carlton LG. Visual information: The control of aiming movements. Qf Exp Psychol 1981;33A:87-93.

28 Van Sonderen JF, Van Gielen CCAM, Denier van De Gon JJ. Motor programmes for goal-directed movements are continuously adjusted according to target location. Exp Brain Res 1989;78:139-46.

29 Camarata PJ, Parker RG, Park SK, Haines SJ, Turner DA Chae $\mathrm{H}$ et al. Effects of 1-methyl-4-phenyl-1,2,5,6 tetrahydropyridine (MPTP) induced hemi-parkinsonism on the kinematics of a two-dimensional multi-joint arm movement in the rhesus monkey. Neuroscience 1992; 48:607-19.

30 Ghez C, Gordon S, Ghilardi MF, Christakos CN, Cooper $\mathrm{SE}$. Roles of proprioceptive input in the programming of arm trajectories. Cold Spring Harb Symp Quant Biol arm trajectories.

31 Teasdale N, Forget R, Bard C, Paillard J, Fleury M, Lamarre $Y$. The role of proprioceptive information for the production of isometric forces and for hand-writing tasks. Acta Psychol (Amst) 1993;82:179-91.

32 Swash M, Fox KP. Normal muscle spindles in idiopathic torsion dystonia. $\mathcal{F}$ Neurol Sci 1976;27:525-7.

\section{Thomas Sydenham and Richard Bright on} chorea

Thomas Sydenham, known as "The British Hippocrates" wrote little of neurological diseases, but his description of chorea ${ }^{1}$ is a classic.

"There is a kind of convulsion, which attacks boys and girls from the tenth year to the time of puberty. It first shows itself by limping or unsteadiness in one of the legs, which the patient drags. The hand cannot be steady for a moment. It passes from one position to another by a convulsive movement, however much the patient may strive to the contrary. Before he can raise a cup to his lips, he does make as many gesticulations as a mountebank; since he does not move it in a straight line, but has his hand drawn aside by the spasms, until by some good fortune he brings it at last to his mouth. He then gulps it off at once, so suddenly and so greedily as to look as if he were trying to amuse the lookers-on."

Chorea (Greek: dance), was used to describe the dancing manias. During an outbreak in 1418 sufferers were regarded as hysterics. They were enjoined to repair to the chapels of St Vitus at Zabern near Strasbourg to plead for the Saint's intervention. A Sicilian martyr under Diocletian (AD 303), St Vitus's remains were moved to France, and, because he was patron of dancers and actors, his altar was used to seek relief from the dancing plague. The dancing mania was a source of great terror: Burton's Anatomy of melancholy (1621) refers to "Chorus Sancti Viti ... they that are taken with it can do nothing but dance till they be dead, or cured."

Sydenham's account made no mention here, nor in chapter 10 "On Rheumatism" that he recognised the association with rheumatic fever. Indeed this association was forged in 1831 by Richard Bright (1797-1858)2:

"A general irritation which so strongly marks chorea" The acute form primarily affected children, in which "we have seen that rheumatism is so intimately connected ... a a peculiar connection." The work of Germaine Sée in 1850 distinguished Sydenham's chorea from paralysis agitans, though mis-citing Parkinson as "Patterson."

J M S PEARCE

1 Sydenham T. On St Vitus's dance. The works of Thomas Sydenham, $M D$. Translated from the Latin edition of Dr Greenhill with a life of the author by RG Latham MD Vol 2. London: The Sydenhain Society, 1850: 257-9.

2 Bright R. Reports of medical cases. Vol 2 Disease of the brain and nervous system: selected with a view of illustrating the symptoms and cure of diseases by reference to morbid anatomy London: Longman, 1831:493.

3 Brown J. Locke and Sydenham and other papers. Edinburgh: David Douglas, 1882:33-135. 